\title{
Assessment of underground mining influences in the area of historic church building
}

\author{
Piotr Strzałkowski ${ }^{1}$, Roman Ścigała ${ }^{I}$ and Katarzyna Szafulera ${ }^{1}$ \\ ${ }^{1}$ Silesian University of Technology, Faculty of Mining and Geology, 2 Akademicka Street, 44-100 \\ Gliwice, Poland
}

\begin{abstract}
The paper presents a case study of the influence of performed mining exploitation on a historic church building and provides a prediction of the effects of the planned exploitation. Due to properly designed and performed structural protections of the building, the exploitation without causing damages to the building's structure was possible. The calculation results indicate that also the planned exploitation should not induce any structural damages to the building. The presented example exhibits the fact that exploitation is possible in areas of this type of buildings if adequate protections are applied and extraction field locations are correctly planned.
\end{abstract}

Keywords: post-mining deformations, forecasting of underground mining influences, mining damages

\section{Introduction}

In Upper Silesia, underground hard coal exploitation has been conducted for over 200 years. The exploitation is a cause of a number of transformations of the natural environment [1-4], as well urban infrastructure [3-9]. Irrespective of the geological and mining conditions, the transformations are accompanied by continuous deformations in the form of subsidence and resulting phenomena. The deformations have been the cause of damages of many buildings, raising public opposition against mining activities. The magnitude of damages caused by mining often used to be very large, which may be exemplified by the city of Bytom. On the other hand, however, Polish science and mining practice can boast of designing and implementing exploitation methods minimizing the damages to, as in the case of exploitation conducted under the centre of the Katowice city [10]. While assessing the capability of a structure to transmit the effects of exploitation, one should consider the structure's characteristics related to the "susceptibility" to a given deformation index [3, 4, 11]. In terms of this capability, church buildings are a specific type of structures. Most of

${ }^{1}$ Corresponding author: katarzyna.szafulera@polsl.pl 
all, this is related to the large dimensions of these buildings, which limits their resistance to deformation as well as the resistance to dynamic effects $[11,12]$. The effects of rock mass tremors in areas of tectonic disturbances requires separate analyses $[13,14]$ due to the values of speed and acceleration exceeding the expected values. In case of predicting the deformation indices of a mining area in which buildings of such type are located, the following their values should be considered: the subsidence, the tilt, the vertical curvatures and the horizontal strain. Besides their maximal values, also the values related to the orientation of the building's walls should be specified. Only the deformation condition specified in such a manner may constitute a starting point for further analyses for professionals specialized in the field of civil engineering in mining area.

This paper presents an example of an analysis of the influence of a former exploitation on a church building and a prediction of the effects of a planned exploitation. The presented case exemplifies the fact that exploitation in the area of buildings "susceptible" to mining effects is possible without causing damages to the building's structure. This is possible due to the application of building prevention methods (reinforcement of structures) and a correctly designed mining exploitation.

\section{Characteristics of the church building}

The church dedicated to Saint Michael Archangel is a free-standing object without basement. It covers an area of approx. $450 \mathrm{~m}^{2}$ and its cubic capacity is approx. $71100 \mathrm{~m}^{3}$. It has been built in the years 1793-1799 on a hill with an elevation of approx. 9m, in a late baroque style. The church is a single-nave building with small extensions at the northern side, in which utility rooms, a vestibule and a vestry are located - Fig. 1.

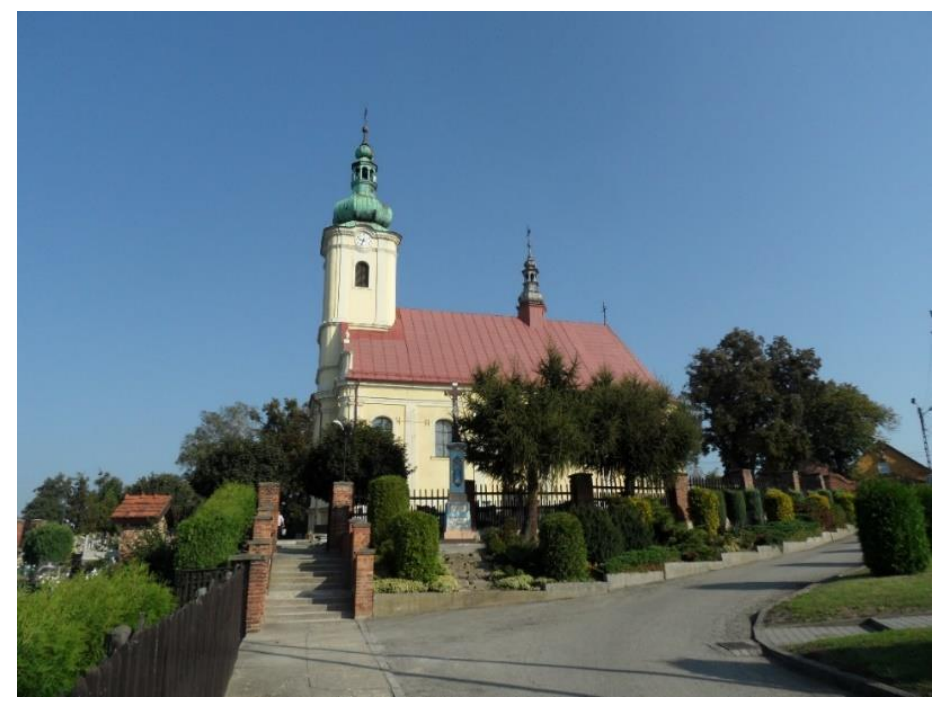

Fig. 1. General view of the church building.

The form of the building is compact, the floor projection is rectangular, elongated, divided at one side. The total length of the church is $30.5 \mathrm{~m}$. The width of the object is variable and ranges from 14.3 to $17.7 \mathrm{~m}$. The height of the building is approx. $20 \mathrm{~m}$ counting from the ground surface to the roof ridge, while the height of the tower is approx. $38 \mathrm{~m}$.

The church's masonry structure constitutes a single body with the tower, without an expansion joint. The foundation is made of bricks and rocks, founded at variable levels 
depending on the inclination of the terrain profile. The wall made of crushed stone based on lime-mortar is $1.39 \mathrm{~m}$ thick ( $2.44 \mathrm{~m}$ thick including the pilaster). The walls are made of ceramic bricks based on lime mortar, covered with plaster work.

Due to obvious reasons, the building was raised without any protections against mining damages. Due to that, works consisting in the performance of internal and external B15class reinforced concrete bracing have been conducted in the years 1989-1990, along with the anchoring of the walls at $9.2 \mathrm{~m}$ and the installation of struts at $8.4 \mathrm{~m} \mathrm{[15].} \mathrm{The}$ protections allowed to classify the building into the $4^{\text {th }}$ category of resistance to mining damages for continuous deformations. It should be added that damages in the forms of wall cracks were repaired on a current basis.

The stocktaking conducted in 2013 and the assessment of the static and dynamic resistance [15] allowed to classify the building into the $2^{\text {nd }}$ category of resistance. Considering the current condition of the building, it may be assumed that it may still be classified to that resistance category.

\section{Analysis of geological and mining conditions}

\subsection{Stratigraphy and lithology}

According to data made available by considered in the research coal mine, rock mass in the vicinity of the building is built of overburden strata and productive Carboniferous formations. The overburden is represented by Quaternary and Neogene layers. The Quaternary formations are of Holocene and Pleistocene origin. Their thickness is variable and ranges from approx. $24 \mathrm{~m}$ to approx. $50 \mathrm{~m}$ in this area. The Quaternary strata are comprised of alluvial sediments represented by sands characterized by variable graining as well as glacial clay and sands with interburdens of gravel. The Neogene formations are of Miocene origin. The thickness of the Neogene strata is variable as well. It varies from approx. $225 \mathrm{~m}$ to approx. $500 \mathrm{~m}$. The Neogene formations are a monotonous series of grey and grey-green marly silts. Moreover, the silts contain interburdens of silty sands and thin seams of tuffs. The Carboniferous formations are built of the "Orzeskie" and "Rudzkie" layers (names used according to Polish classification of Carboniferous layers). The "Orzeskie" beds are characterized by variable thickness. In terms of lithology, claystones and mudstones are predominant in the profile. Sandstone beds are less common. The claystones are grey and dark-grey, often with varying inclusions of sand. The beds are characterized by the occurrence of single and larger clusters of sideritic concretions and plant detritus. The sandstones present in the "Orzeskie" layers are most often fine-grained. 19 coal seams have been documented (from No. 340/2 to No. 363), which usually accompany the claystone beds. The coal seams are very numerous, yet often irregular in form, with varying quality and thickness, rarely reaching approx. $2.0 \mathrm{~m}$.

In terms of lithology and deposition conditions, the "Rudzkie" layers resemble the "Orzeskie". The claystones constituting the beds contain variable inclusions of sand, locally giving way to mudstones. 


\subsection{Tectonics}

According to available mining maps and geological cross-section, tectonics of the deposit has largely been disturbed in the area of the church. The following tectonic faults are present in the vicinity of the object:

- To the north-east of the building, the "G I" fault runs from north-west to southeast. The fault throws the beds towards north-east. The throw height in the area is approx. $80 \mathrm{~m}$.

- To the north-west of the building, the "G II" fault perpendicularly reaches the "G I" fault. The fault runs from north-east to south-west. The "G II" fault throws the beds by approx. $20 \mathrm{~m}$ to north-west. Another fault, perpendicular to this one, forms a step fault zone behind the "G II" fault. The fault throws the beds into the south-eastern direction at a height from 8 to $18 \mathrm{~m}$.

- Another fault zone - the "K II" fault, is located to the south and south-east of the building. Initially, the zone runs from the north-east to the south-east and subsequently runs rather latitudinally. The general throw direction is northwestern, while the throw height is approx. $40 \mathrm{~m}$. The zone is accompanied by faults with smaller throws reaching form approx. $1 \mathrm{~m}$ to approx. $6 \mathrm{~m}$.

\subsection{Former mining exploitation}

It is recognized, on the basis of available mining maps with locations of conducted in the past mining exploitation, that in the considered area exploitation using a longwall system with caving to a height from $1.1 \mathrm{~m}$ to $3.1 \mathrm{~m}$ was led in the following coal seams:

- $346 / 1$ - during the years: 1986 - 89, at depth range $520 \mathrm{~m}-580 \mathrm{~m}$.

- $347 / 1$ - during the years: $1991-95$, at depth range $560 \mathrm{~m}-610 \mathrm{~m}$.

- $356 / 1$ - during the years: $1984-2000$, at depth range $670 \mathrm{~m}-820 \mathrm{~m}$.

- $357 / 1$ - during the years: $1987-2004$, at depth range $670 \mathrm{~m}-870 \mathrm{~m}$.

- $\quad 358 / 1$ - during the years: $1984-1992$, at depth range $700 \mathrm{~m}-770 \mathrm{~m}$.

- 358/2 - during the years: 1986 - 1992, at depth range $670 \mathrm{~m}-740 \mathrm{~m}$..

- 360/1 - during the years: 1985 - 2007, at depth range $670 \mathrm{~m}-930 \mathrm{~m}$.

- 361 - during the years: 2010 - 2011, at depth range $880 \mathrm{~m}-890 \mathrm{~m}$.

- 362/1 - during the years: 2014 - 2015, at depth range $930 \mathrm{~m}$.

- 401/2 - during the years: 2006 - 2010, at depth range $870 \mathrm{~m}-900 \mathrm{~m}$.

- $\quad 403 / 2$ - during the years: 2006 - 2013, at depth range $880 \mathrm{~m}-910 \mathrm{~m}$.

\subsection{Currently conducted and planned mining exploitation}

In the area of the church building, mining exploitation is conducted and planned in the coal seams: $357 / 1,359 / 1,363,404 / 1$, and 404/2. The basic data concerning the mining and geological conditions has been presented in table 1. Fig. 2 presents a sketch of the locations of longwalls in relation to the church building. 
Table 1. Basic data regarding the currently conducted and planned mining exploitation in the vicinity of the church building (according to available mining maps)

\begin{tabular}{|c|c|c|c|c|c|c|c|}
\hline $\begin{array}{l}\text { Seam } \\
\text { No }\end{array}$ & $\begin{array}{l}\text { Longwall } \\
\text { No }\end{array}$ & $\begin{array}{l}\text { Start } \\
\text { expl. } \\
\text { date }\end{array}$ & $\begin{array}{l}\text { End } \\
\text { expl. } \\
\text { date }\end{array}$ & $\begin{array}{l}\text { Thick } \\
\text { ness } \\
{[\mathrm{m}]}\end{array}$ & $\begin{array}{l}\text { Dip } \\
\text { angle } \\
\text { [deg] }\end{array}$ & $\begin{array}{c}\text { Depth } \\
\text { (avg) } \\
{[\mathrm{m}]}\end{array}$ & $\begin{array}{l}\text { Dis } \\
\text { tance } \\
{[\mathrm{km}]}\end{array}$ \\
\hline $357 / 1$ & $G-32$ & $01-02-2017$ & $31-03-2018$ & 2.4 & 7 & 845 & 0.57 \\
\hline $359 / 1$ & $G-31$ & $01-01-2020$ & $31-12-2021$ & 2.0 & 9 & 795 & 0.47 \\
\hline $359 / 1$ & $G-32$ & $01-01-2019$ & $31-12-2020$ & 2.0 & 9 & 834 & 0.76 \\
\hline 363 & $\mathrm{~K}-1$ & $01-07-2018$ & $01-05-2019$ & 4.3 & 6 & 980 & 0.46 \\
\hline 363 & $\mathrm{~K}-2$ & $01-08-2019$ & $01-06-2020$ & 4.3 & 7 & 955 & 0.42 \\
\hline 363 & $K-4$ & $01-10-2020$ & $31-12-2021$ & 4.3 & 2 & 935 & 0.42 \\
\hline 363 & $K-5$ & $01-05-2022$ & $01-12-2023$ & 4.3 & 7 & 915 & 0.47 \\
\hline $404 / 1$ & $C-5$ & $01-04-2017$ & $01-03-2018$ & 2.0 & 7 & 995 & 1.42 \\
\hline $404 / 2$ & $C-3$ & $01-10-2018$ & $01-12-2019$ & 4.2 & 2 & 990 & 1.70 \\
\hline $404 / 2$ & $C-4$ & $01-02-2020$ & $01-08-2021$ & 4.2 & 2 & 1005 & 1.60 \\
\hline $404 / 2$ & $C-5$ & $01-01-2022$ & $01-03-2023$ & 3.2 & 3 & 1025 & 1.52 \\
\hline $404 / 2$ & $\mathrm{~N}-10$ & $01-06-2019$ & $01-01-2020$ & 2.5 & 4 & 935 & 0.44 \\
\hline $404 / 1$ & $F-31$ & $01-07-2017$ & $31-12-2019$ & 2.8 & 6 & 860 & 0.97 \\
\hline $404 / 1$ & $F-32$ & $01-01-2020$ & $31-12-2021$ & 3.5 & 8 & 925 & 0.67 \\
\hline
\end{tabular}

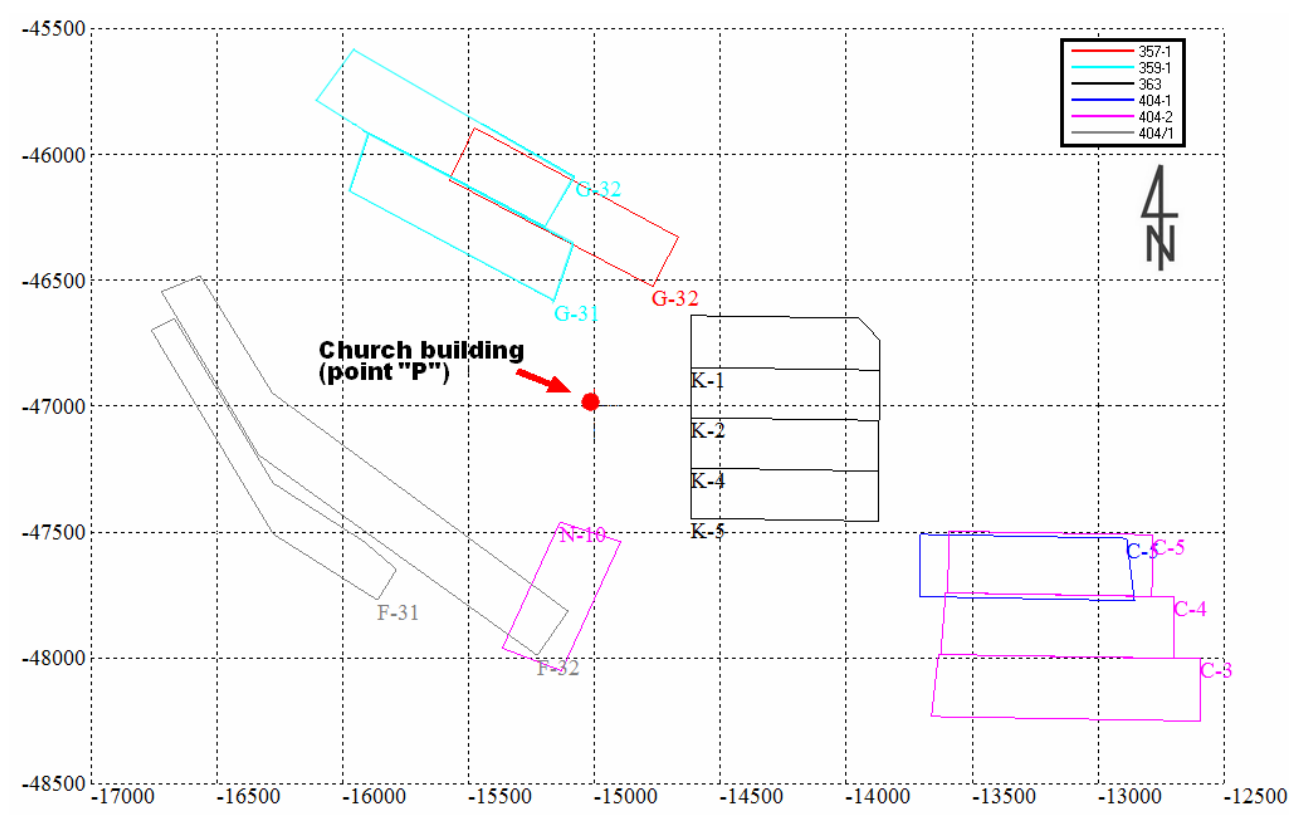

Fig. 2. The sketch of longwalls location in relation to the church building.

\section{The influence of conducted exploitation on the surface in the area of the building in view of the measurement results}

To monitor the effects of mining exploitation in the area of the church, geodetic measurements were conducted for ground points and wall bench marks located on the church foundations. The ground bench marks with numbers from 1A to 6 were located around the church building. Location of control points is shown in fig.3. The first measurement was conducted on 12.08.1992. The measurements were conducted depending on the intensity of the effects of mining exploitation in intervals ranging from one quarter to one year. Until June 2018, a total of 65 measurements have been taken. 
Additionally, three wall bench marks: K1, K2 and K3, have been placed in 1992, subject to measurements with similar frequency as the ground points. In October of 2001, two additional bench marks, K1A and K2A, were placed on the foundations of the church building.

Analyzing the results of measurements conducted for the ground bench marks around the church (points 1A - 6) and the wall bench marks located on the foundations (points 11/463 K1, K2, K3, K1A, K2A), it should be concluded, that the subsidence of the surface caused by mining exploitation in the years 1992-2018 proceeded systematically at a constant intensity. The maximal subsidence was measured in June 2018 at the $5 \mathrm{~A}$ bench mark, reaching $-806 \mathrm{~mm}$, while the maximal subsidence measured for the foundation of the building reached $-728 \mathrm{~mm}$ in the K2 point. In the years $1992-2018$, the movements of the rock mass registered using the bench marks in the area of the building have been observed to decrease in three periods: in December 2000, August 2006 and June 2017. Between June 2017 and June 2018, slight increases in subsidence of the bench marks located on the building have been observed.
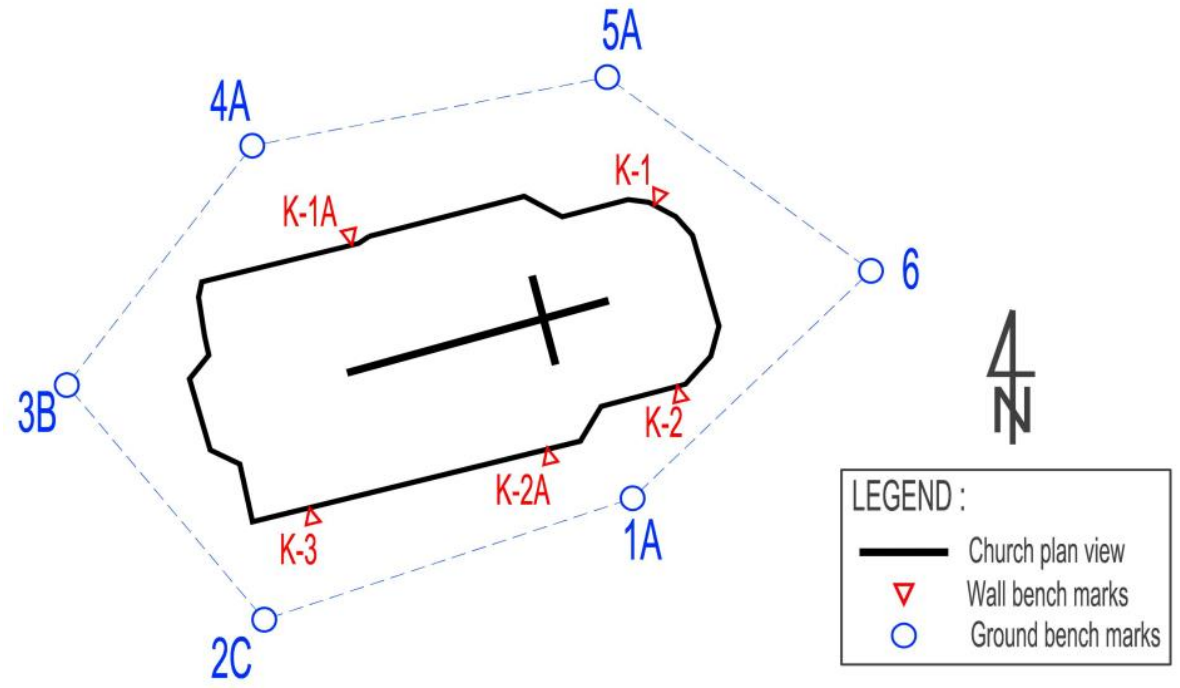

Fig.3. Location of measuring points in the neighborhood of the church building

\section{The influence of planned exploitation on the church building in the light of performed calculations}

The following assumptions have been made in the calculations using the W. Budryk S. Knothe [16] theory:

- the following values of the parameters were assumed:

- coefficient of roof control: $\mathrm{a}=\mathbf{0 . 8}$,

- parameter describing influence range: $\operatorname{tg} \boldsymbol{\beta}=\mathbf{2 . 0}$,

- the coefficient of proportionality in Avershin's relationship: $\mathbf{B}=\mathbf{0 . 3 2} \mathbf{r}$,

- extraction boundary: $\mathbf{d}=\mathbf{0} \mathbf{~ m}$.

- calculations were carried out by using DEFK - Win software [17], for asymptotic state of deformation, assuming that coal seams are horizontal, planar (angle of dip $\gamma=0^{\circ}$ ). 
The results of the calculations have been presented in table 2. The calculations were performed for one characteristic calculation point $\mathrm{P}$, located at the centre of gravity of horizontal plan of the building. The table presents the following values of deformation indices:

- $\mathrm{w}$ - subsidence, $\mathrm{mm}$

- $\mathrm{T}_{\max } \quad$ - maximal tilt, \%o

- $\mathrm{T}_{\alpha 1} \quad$ - tilt in the direction $\alpha_{1}, \%$

- $\mathrm{T}_{\alpha 2} \quad$ - tilt in the direction $\alpha_{2}, \%$

- $\mathrm{E}_{\max }$ - maximal horizontal strain, \%o

- $\mathrm{E}_{\alpha 1} \quad$ - horizontal strain in the direction $\alpha_{1}, \%$

- $\mathrm{E}_{\alpha 2}$ - horizontal strain in the direction $\alpha_{2}, \%$

- $\mathrm{E}_{1}, \mathrm{E}_{2}$ - principal horizontal strain, \%o

- $\mathrm{K}_{\max }$ - maximal vertical curvature, $1 / \mathrm{km}$

- $\mathrm{K}_{\alpha 1}$ - vertical curvature in the direction $\alpha_{1}, 1 / \mathrm{km}$

- $\mathrm{K}_{\alpha 2}$ - vertical curvature in the direction $\alpha_{2}, 1 / \mathrm{km}$

- $\mathrm{K}_{1}, \mathrm{~K}_{2}$ - principal vertical curvature, $1 / \mathrm{km}$

The directions in which the values of the deformation indices were calculated $\left(\alpha_{1}\right.$ and $\alpha_{2}$ ) were specified along the directions parallel to the external walls of buildings.

Table 2. Predicted values of deformation indices at the location of calculation point "P"

\begin{tabular}{|c|c|c|c|c|c|c|c|}
\hline $\begin{array}{l}\text { Deformation } \\
\text { index: }\end{array}$ & $\begin{array}{c}\mathrm{w} \\
{[\mathrm{mm}]}\end{array}$ & $\begin{array}{l}\mathrm{T}_{\max } \\
{[\% 0]}\end{array}$ & $\begin{array}{c}\mathrm{T}_{\alpha 1} \\
{[\% 0]}\end{array}$ & $\begin{array}{c}\mathrm{T}_{\alpha 2} \\
{[\%]}\end{array}$ & $\begin{array}{l}E_{\max } \\
{[\% 0]}\end{array}$ & $\begin{array}{l}E_{\alpha 1} \\
{[\% 0]}\end{array}$ & $\begin{array}{l}E_{\alpha 2} \\
{[\% 0]}\end{array}$ \\
\hline $\begin{array}{c}\text { Value } \\
\text { at point „P”: }\end{array}$ & -49.0 & 0.57 & -0.53 & 0.22 & 1.01 & 0.97 & 0.24 \\
\hline $\begin{array}{l}\text { Deformation } \\
\text { index: }\end{array}$ & $\begin{array}{c}E_{1} \\
{[\% 0]}\end{array}$ & $\begin{array}{c}\mathrm{E}_{2} \\
{[\% 0]}\end{array}$ & $\begin{array}{c}\mathrm{K}_{\max } \\
{[1 / \mathrm{km}]}\end{array}$ & $\begin{array}{c}\mathrm{K}_{\alpha 1} \\
{[1 / \mathrm{km}]}\end{array}$ & $\begin{array}{c}\mathrm{K}_{a 2} \\
{[1 / \mathrm{km}]}\end{array}$ & $\begin{array}{c}\mathrm{K}_{1} \\
{[1 / \mathrm{km}]}\end{array}$ & $\begin{array}{c}\mathrm{K}_{2} \\
{[1 / \mathrm{km}]}\end{array}$ \\
\hline $\begin{array}{c}\text { Value } \\
\text { at point „,P”: }\end{array}$ & 1.01 & 0.19 & -0.007 & -0.006 & -0.002 & -0.001 & -0.007 \\
\hline
\end{tabular}

Fig. 4 presents the contour map of predicted subsidence and the categories of mining areas [18]. Categories of mining areas, describing the threat level connected with continuous deformations (according to Polish underground mining regulations) were determined on the basis of maximal horizontal strain values.

Based on the calculation results presented in table 2 and in fig. 4, it may be concluded that all the deformation index values will fit within the range of the $1^{\text {st }}$ category of mining areas. 


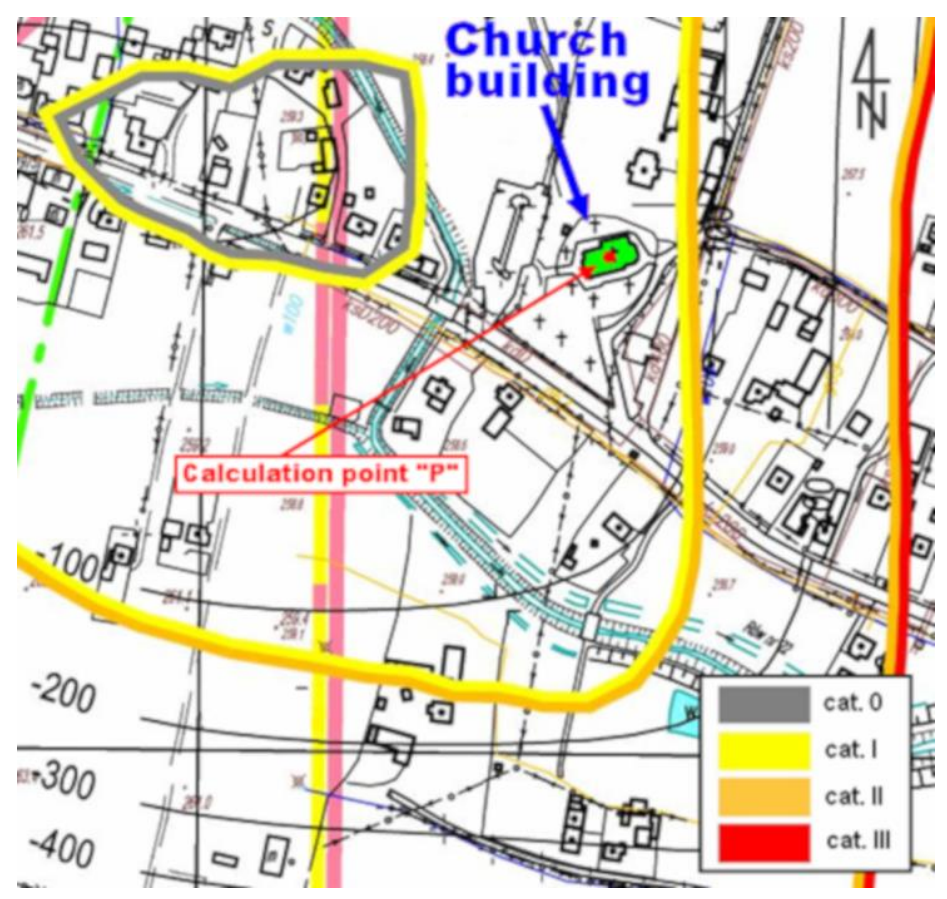

Fig. 4. Contours of predicted subsidence (in $\mathrm{mm}$ ) and the zones of categories of mining area determined on the basis of the extreme horizontal strain values.

\section{Summary and conclusions}

The article presents an example of an analysis of the underground mining exploitation influences on a historic church building. The conducted analyses allow to make the following remarks and conclusions:

1. Due to proper structural protections, the building withstood the effects of the mining exploitation conducted throughout the years without being subject to structural damages. In the period between 1992 and 2018, the building was subjected to subsidence reaching approx. $0.7-0.8 \mathrm{~m}$ at most. It should be assumed that after the occurrence of surface deformations, the resistance of the building was decreased to the $2^{\text {nd }}$ category.

2. In view of the results of the calculations, the planned mining exploitation will cause $1^{\text {st }}$ category deformations. It may thus be assumed that no structural damages will be caused to the building.

3. The presented case constitutes an example of the possibility of conducting mining exploitation in an area of a valuable historic object.

\section{References}

1. M Chudek: Geomechanika z podstawami ochrony środowiska górniczego i powierzchni terenu. Wydawnictwo Politechniki Śląskiej. Gliwice (2002)

2. M Chudek: Mechanika górotworu z podstawami zarzadzania ochrona środowiska $w$ obszarach górniczych $i$ pogórniczych. Wydawnictwo Politechnika Śląska Gliwice (2010) 
3. H Kratzsch H: Mining Subsidence Engineering. Springer-Verlag, Berlin, Heidelberg, New York (1983)

4. J Kwiatek: Obiekty budowlane na terenach górniczych. GIG. Katowice (2007)

5. M Marschalkoa, M Duraja, D Niemiec, I Yilmazb, A Pryvalovc: Churches influenced by underground mining in the Karvina region used for the purposes of geotourism. Proc. Engineering Vol. 161, pp. $2271-2275$ https://doi.org/10.1016/j.proeng.2016.08.827 (2016)

6. L Florkowska: Analysis of the impact of longwall mining on sacred historic building. Architecture, Civil Engineering, Environment No 2, pp. 15-27. Silesian University of Technology (2013)

7. R Misa, A Sroka, K Tajduś, M Dudek: Analytical design of selected geotechnical solutions which protect civil structures from the effects of underground mining. Journal of Sustainable Mining 18, pp. 1-7. https://doi.org/ 10.1016/j.jsm.2018.10.002 (2019)

8. F L Gayarre, M I Álvarez-Fernández, C González-Nicieza, A E Álvarez-Vigil, G Herrera García: Forensic analysis of buildings affected by mining subsidence. Engineering Failure Analysis 17, pp. 270-285, doi:10.1016/j.engfailanal.2009.06.008 (2010)

9. J Rusek, K Firek, A Wodyński: Assessing the influence of mining impacts on buildings using SVM and MLR method. IOP Conf. Series: Materials Science and Engineering 471, doi:10.1088/1757-899X/471/5/052060 (2019)

10. E Strzałkowska, P Strzałkowski: Ostatnie kopalnie w centrum Katowic. Czasopismo Naukowo-Techniczne Górnictwa Rud Cuprum No. 2 (87), pp. 49-58 (2018)

11.P Strzałkowski: Zarys ochrony terenów górniczych. Wydawnictwo Politechniki Śląskiej, Gliwice (2010)

12. G Mutke: Zasady stosowania górniczej skali intensywności sejsmicznej GSIS-2017 do prognozy $i$ oceny oddzialywania wstrzasów indukowanych eksploatacja na obiekty budowlane oraz klasyfikacji ich odporności dynamicznej. Katowice, GIG, seria: Instrukcje Nr 23 (2018)

13. E Pilecka, D Szwarkowski: The influence of the fault zone width on land surface vibrations after the high-energy tremor in the "Rydultowy-Anna" hard coal mine. E3S Web of Conferences, Vol. 3602007 (2017)

14. E Pilecka, K Stec, R Szermer-Zaucha: The influence of the Ktodnica fault tectonic zone on the degree of damage to buildings resulting from high magnitude tremors. Technical Transactions. Czasopismo Techniczne. vol. 7, pp. 53-64 (2017)

15. Ekspertyza budowlana budynku kościoła, budynku probostwa, ogrodzenia i schodów terenowych znajdujących się w K. przy ul. K. Grupa Rzeczoznawców SITG Zarządu Oddziału Rybnik (2013)

16. S Knothe: The equation of finally formed profile of subsidence trough. Cracow, Archive of Mining and Metallurgy, vol. 1 iss. 1, pp. 22-38 (1953)

17. $\mathrm{R}$ Ścigała: The identification of parameters of theories used for prognoses of post mining deformations by means of present software. Arch. Mining Sci, Vol. 58 iss. 4, pp. 1347-1357, DOI 10.2478/amsc-2013-0093 (2013)

18. Instrukcja GIG nr 12 : Zasady oceny możliwości prowadzenia podziemnej eksploatacji górniczej z uwagi na ochronę obiektów budowlanych. Publishing House of Central Mining Institute, Katowice (2000). 